\section{Fatty Metaplasia of the Filum Terminale of the Frog}

THE following observations were made during a search for preparations which would permit assays of various enzymes in tissue samples containing glial cells only. Such an opportunity seemed to be provided by the filum terminale which is commonly considered a glial remnant of the fotal sacral cord ${ }^{2}$. Tobias, Clark, and Gerard ${ }^{2}$ measured the respiration of the filum terminale of the cat and concluded that glial tissue had a rather high rate of respiration, comparable to that of neurones. The filum terminale of Rana catesbiena was used in our work because of its unusual size. A smaller material of 8 specimens of Rana pipiens was also examined with the same results.

Assays of the frog filum terminale indicated very little, if any, succinic dehydrogenase activity but extremely variable DPN-diaphorase activity per wet weight or per mg of protein. Searching for histological differences which might reflect this variability, we found that the filum terminale of normal frogs undergoes various degrees of fatty metaplasia. Although we have not found previous reference to this in the literature, fatty metaplasia of the filum terminale of the frog seems to be a physiological phenomenon; we could not relate it to the state of health or nutrition of the frogs; it did not seem to represent a pathological fatty degeneration because the fatty changes were confined to the filum and no fatty changes were seen in the spinal cord. A.ll our frogs were studied during summer and autumn. The extent of fatty metaplasia was usually the same throughout any given filum, but it varied greatly among animals. The following observations were made in histochemical preparations for lactic dehydrogenase and DPN-diaphorase which were counterstained with fat red; longitudinal and transverse sections of the filum were used.

'Normal' glial cells in the filum terminale of the frog showed intense lactic dehydrogenase and DPN-diaphorase activity throughout their cytoplasm and processes (Fig. 1). Compared with glial cells in mammalian brains, these cells could not be identified as being either astrocytes or oligodendroglia. A slight degree of fatty metaplasia was evidenced by a single fat droplet in the cell body. More advanced fatty metaplasia was indicated by varioussized large fat droplets, most of which by far exceeded the original volume of the cell (Fig. 2). The cytoplasm of such cells was stretched to a thin spherical shell and the peri-

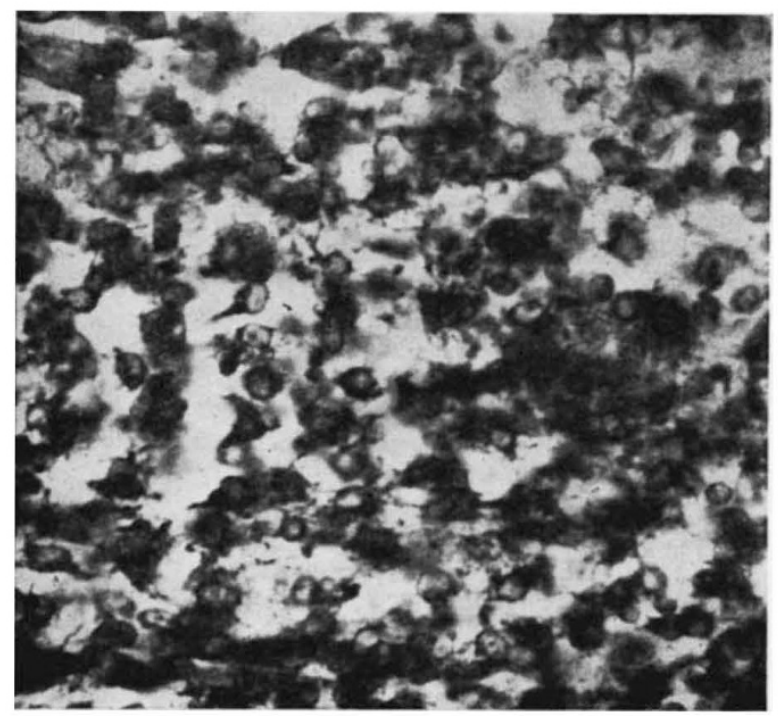

Fig. 1. Intense reaction for DPN-diaphorase in the cells of the flum terminale of the frog; no fat was found in this preparation

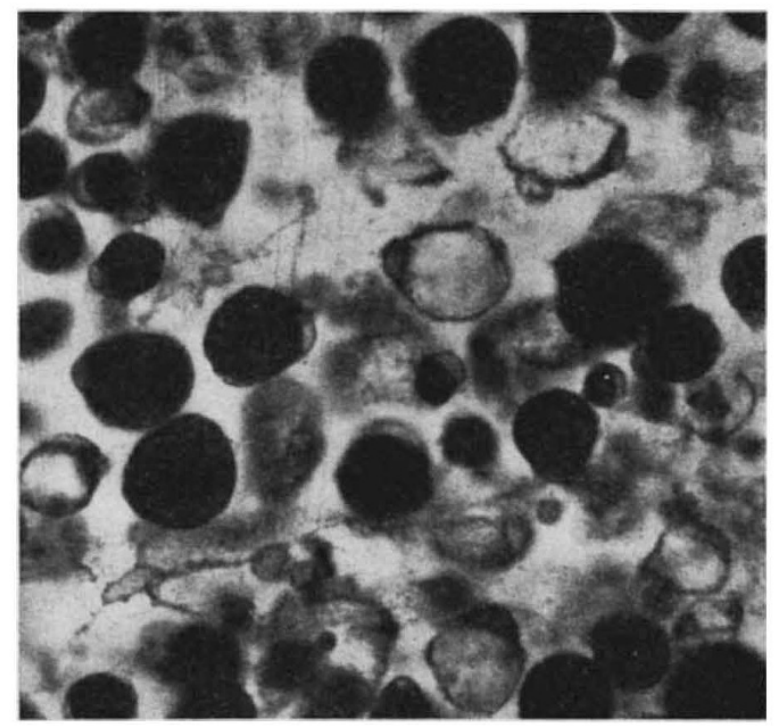

Fig. 2. Fatty metaplasia of flum terminale; DPN-diaphorase, counterstained with fat-red. The fat droplets had been removed from some of the cells, which show only an empty shell of cytoplasm, demonstrated by enzyme activity. In the original preparation, fat is bright red and

karyon was flattened, as in adipose cells. The fat droplets had been removed from some cells during cutting, and these cells appeared as empty, spherical vesicles (Fig. 2). It appeared that the amount of enzyme activity was in a crude inverse proportion to the fatty metaplasia in the cells. At early phases of fatty metaplasia, the enzyme activity in the cells was not visibly weaker than normal, but very little enzyme activity was present in the cells of fila with extreme fatty metaplasia.

These observations offer no clues as to the possible causes of this type of fatty metaplasia which seems to represent a physiological process in the filum terminale of the frog. The ability to store fat, much like adipose cells do, strikingly distinguishes the tissue of the filum of the frog from that of any other portion of the central nervous system. It seems quite clear that the filum terminale of the frog is not suitable for examination of glial metabolism.

This work was supported by U.S. Public Health grant B3250.

Reinhard L. Friede

Mental Health Research Institute,

University of Michigan, Ann Arbor.

${ }^{1}$ Kappers, C. V., Ariens, Huber, G. C., and Crosby, E. C., The Comparative Anatomy of the Nervous System of Vertebrates including Man (Hafner, New York, 1960).

soblas, J. M., Clark, D. B., and Gerard, R. W., Fed. Proc., 1, 85 (1942).

\section{PATHOLOGY}

\section{Effect of Colchicine on Human Tumours transplanted in Cheek Pouch of Syrian Hamster}

THe human tumour transplanted in the cheek pouch of the Syrian hamster has proved to be a useful tool for the examination of potential anti-tumour agents ${ }^{1,2}$. What appears to be an obvious advantage in using transplantable human tumours over transplantable animal tumours in chemotherapy investigations lies in the fact that a given compound can be assayed on cells of human origin growing in an in vivo system. However, at least two conditions would have to be fulfilled prior to making such a comparison: (1) transplanted human tumours should not 